present celebrations by a special session of the Diet at which a sum of approximately $£ 9,000$ was voted for the further study of the ancient history, culture and literature of the Finnish people, and by the presence of more than 4,000 people when M. Mamtere, Minister of Education, opened an exhibition, at which a large collection of pictures by Gallen Kalicia, Finland's greatest painter of Kalevala subjects, was the centre of attraction.

\section{Training the Industrial Chemist}

THE important subject of the training of an in. dustrial chemist was discussed by Mr. Thomas Donaldson in his address as chairman of the Glasgow Section of the Society of Chemical Industry at a meeting held jointly with the Glasgow Section of the Institute of Chemistry in the Royal Technical College, Glasgow, on March 1. Mr. Donaldson is general technical manager of the Explosives Group of Imperial Chemical Industries, Ltd., and though he made it clear that he was expressing his own personal opinions, his long industrial experience and his position as a governor of the Royal Technical College give him an opportunity of forming an unbiased opinion by being able to look at the problem from both sides. His chief criticism of the present system is that the training usually considered necessary to equip a man for chemical industry is too long. In Scottish universities a student of chemistry takes an honours degree requiring four years study and then normally pursues research leading to a doctorate. This research period extends over three years for a Ph.D. and then, at the age of about twenty-four years, the man endeavours to obtain an industrial position. Once in industry, it requires a further two years training before the man can be considered to be a thoroughly efficient member of his profession, since the university training has scarcely touched on industrial chemistry. Mr. Donaldson suggested that instead of the present system a man should take a three years pass degree, and he could then decide whether he would continue to pursue a technical career. If not, then, by two years training on the commercial side, he could become a thoroughly efficient technical salesman. If he decided to remain on the technical side he had two alternatives. $\mathrm{He}$ could complete his honours degree and do one year's post-graduate research, or he could take a two years course in applied chemistry. On this matter of starting research, Mr. Donaldson said that it is far more important that students should be trained in the methods of research rather than that they should solve any particular problem.

\section{Annual General Meeting of the Institute of Chemistry}

AT the fifty-seventh annual general meeting of the Institute of Chemistry held on March 1, Prof. Jocelyn Thorpe (president), in moving the adoption of the annual report, said that the register of the Institute now contains the names of 6,285 fellows and associates and more than 800 registered students. The Institute is in a strong position financially, and has co-operated with many other organisations in matters of public importance during the year. Negotiations are on foot for closer co-operation with other societies devoted to chemistry, particularly the Chemical Society and the Society of Chemical Industry. Continuing, Prof. Thorpe dealt with the importance of individualism in professional scientific life. Having regard to the bearing of the subject on the development of team work in research, he emphasised especially the desirability of giving due credit to the individual worker who initiated and developed ideas. He contrasted the present conditions for research work with those existing some forty years ago in the big German factories, where there was little or no intercourse between the members of the research section, who never seemed to talk to one another, being fearful lest they should communicate to their fellow-workers something of the investigations on which they had been engaged, and thus lose the credit due to themselves. This competitive method has now practically died out. The following were elected officers of the Institute for the ensuing year: President, Prof. Jocelyn Thorpe; Vice-Presidents, Mr. W. J. A. Butterfield, Sir George Clayton, Dr. A. E. Dunstan, Mr. F. G. Edmed, Dr. H. H. Hodgson, Mr. W. H. Roberts; Hon. Treasurer, Mr. P. H. Kirkaldy.

\section{Training in Food Technology}

In Nature of February 23, we summarised the proceedings at a meeting held under the auspices of the Food Group of the Society of Chemical Industry, to discuss a paper on this subject by Dr. H. B. Cronshaw, editor of Food Manufacture, the Manufacturing Chemist (not the Industrial Chemist, as erroneously stated in the notice), the Food Industries Weekly, etc. Dr. Cronshaw writes to us to make clear that he was advocating an extension, rather than a restriction, of the food chemist's general scientific training, particularly in pre-graduate days, in the direction of physical chemistry and of biology (including bacteriology); this is not in any way inconsistent with increased technological facilities, both in teaching and in research, at the post-graduate stage. $\mathrm{He}_{e}$ is in agreement with his fellow-members of the Food Group that the food technologist must be a scientific worker first and foremost.

\section{German Physical Congress}

THE Physikalische Zeitschrift of December 1, 1934, contains the communications and discussions made to the German Conference of Physics held in Pyrmont last September. The section on low temperatures includes reports on the magnetic method for attaining low temperatures, on supra-conductivity, on the calorimetric behaviour of metals at low temperatures, on reflection of light and photo-electric effect at low temperatures, etc. The other section on atomic and nuclear physics includes communications on absorption lines, discharge tubes, molecular oscillations in sound-wave phenomena, positrons, cosmic particles, and electron opties, etc. 